\title{
Cheatgrass Invasion in Salt Desert Shrublands: Benefits of Postfire Reclamation
}

\author{
Brad D. Jessop ${ }^{1}$ and Val Jo Anderson ${ }^{2}$ \\ Authors are ${ }^{1}$ Research Associate and ${ }^{2}$ Professor of Rangeland Ecology, Plant and Animal Sciences Department, Brigham Young University, \\ Provo, UT 84602.
}

\begin{abstract}
In 1998, fires burned more than 11330 ha of rangeland on Dugway Proving Ground in Utah's west desert. Postfire revegetation was implemented in 2 affected salt desert shrub communities (greasewood; Sarcobatus vermiculatus Hook. and black sagebrush/ shadscale; Artemisia nova A. Nels; Atriplex confertifolia Torr. \& Frem.) to deter cheatgrass (Bromus tectorum L.) encroachment. We monitored cheatgrass densities for 3 years after the fire in burned drill seeded, burned not-seeded, and unburned plots to assess the rate of invasion and determine the impact on cheatgrass of drill seeding perennial species. Cheatgrass invaded quickly in both shrub sites following the fires. In the greasewood site, drill seeded species germinated but did not establish. This was likely due to a combination of soil salinity and extremely dry weather conditions during the second year of the study. Drill seeded species in the black sagebrush site germinated and established well, resulting in the establishment of 16.5 perennial grasses $\cdot \mathrm{m}^{-2}$ and $1356 \mathrm{shrubs} \cdot \mathrm{ha}^{-1}$. Cheatgrass densities were consistently lower in drill seeded versus notseeded plots, although these were not always statistically different when Bonferroni comparisons were considered. The initial decrease in cheatgrass densities in drill seeded plots may have resulted from soil disturbance coupled with extremely low precipitation rather than competitive effects. Nevertheless, as seeded species mature and increase their competitive ability, we predict long-term suppression of cheatgrass in the absence of further disturbance.
\end{abstract}

\section{Resumen}

En 1998, el fuego quemó más de 11330 ha de pastizal en Dugway Proving Ground en la región desértica oeste de Utah. Se implementaron acciones de revegetación posterior al fuego en dos comunidades arbustivas halófilas desérticas ("Greasewood"; Sarcobatus vermiculatus Hook. y "Black sagebrush"/"Shadscale”; Artemisia nova A. Nels; Atriplex confertifolia Torr. \& Frem.) para prevenir la invasión del "Cheatgrass" (Bromus tectorum L.). Monitoreamos las densidades de "Cheatgrass" durante tres años después del fuego en áreas: quemadas y sembradas mecánicamente, quemadas sin sembrar y áreas sin quemar, para evaluar la tasa de invasión y determinar el impacto de la siembra de especies perennes sobre el "Cheatgrass." Después del fuego, el "Cheatgrass" invadió rápidamente ambos sitios de comunidades arbustivas. En el sitio "Greasewood,” las especies sembradas germinaron pero no se establecieron, esto probablemente debido a la combinación de la salinidad del suelo y las condiciones climáticas extremadamente secas que ocurrieron durante el segundo año del estudio. En el sitio "Black sagebrush," las especies sembradas germinaron y se establecieron bien, estableciéndose 16.5 zacates perennes o m-2 y 1356 arbustos o ha-2. Las densidades de "Cheatgrass" fueron consistentemente más bajas en las parcelas sembradas que en las no sembradas, aunque las diferencias no siempre fueron estadísticamente diferentes cuando se compararon con la prueba de Bonferroni. La disminución inicial de las densidades del "Cheatgrass" en las parcelas sembradas pudo haber resultado por el disturbio del suelo en conjunto con la precipitación extremadamente baja, mas que por efectos competitivos. No obstante, conforme las especies sembradas maduran e incrementan su capacidad competitiva, nosotros predijimos una supresión a largo plazo del "Cheatgrass" en ausencia de mas disturbio.

Key Words: black sagebrush, Bromus tectorum, drill seeding, greasewood, invasive, rehabilitation

\section{INTRODUCTION}

One of the greatest threats to ecosystems in semiarid regions of the western United States is the invasion of cheatgrass (Bromus tectorum L.). Once established, particularly in disturbed areas, cheatgrass can become a major obstacle preventing the recolonization and growth of more desirable native perennial species (Young et al. 1969; Young and Evans 1973, 1978). The rapid germination and early spring growth of cheatgrass allows

Research was funded in part by US Department of Defense, Dugway Proving Ground, Utah. At the time of research, Jessop was a graduate student, Botany and Range Science, Brigham Young University, Provo, UT 84602.

Correspondence: Brad Jessop, Plant and Animal Sciences Dept, 275 WIDB, Brigham Young University, Provo, UT 84602. Email: bdjessop@hotmail.com

Manuscript received 14 February 2005; manuscript accepted 28 January 2007. it to utilize moisture and nutrients that are critical for native plant growth and survival (Melgoza et al. 1990; Smith and Nowak 1990). This preemptive use of resources puts native plants at a competitive disadvantage.

Cheatgrass also deters native perennial plant growth by altering natural fire regimes. Cheatgrass is extremely flammable and grows in dense stands in shrub interspaces, providing the accumulation of fine fuels necessary to carry fire to widely spaced woody plants (Young and Evans 1978; Whisenant 1990). The presence of a highly flammable continuous fuel load substantially increases the probability, frequency, and intensity of fire (Knapp 1996). Fire frequency in some cheatgrass infested rangelands has increased from 60 to 100 years to 3 to 5 years (Whisenant 1990). This increase in fire frequency combined with the propensity of cheatgrass to germinate quickly and produce large numbers of viable seeds perpetuates 
its growth and dominance by inciting "cyclic environmental degradation" that continually eliminates most native competitors (Young and Evans 1978).

The reclamation of cheatgrass-dominated lands has received much attention from ecologists and land managers throughout the Intermountain West, particularly in sagebrush (Artemisia spp.) steppe regions. Less consideration has been given to reclaiming cheatgrass-infested rangelands in other areas such as salt desert shrublands. This may be because these lowprecipitation $(<200 \mathrm{~mm}$ annually), high-salinity, climatically harsh environments are inherently hard to reclaim following disturbance and historically have been impacted minimally by cheatgrass. Shrub die-off in the early 1980s (Dobrowolski and Ewing 1990) coupled with successive years (1983-1985) of extremely wet conditions has been linked to annual grass invasion and alteration of fire regimes in salt desert shrublands (West 1994). Increased fire occurrence and grazing pressure (Harper et al. 1996) continue to promote the expansion of cheatgrass into salt desert shrub communities.

For this study, we focused on the impact of drill seeding perennial species on cheatgrass encroachment following fire in depleted greasewood (Sarcobatus vermiculatus Hook.) and black sagebrush/shadscale (Artemisia nova A. Nels; Atriplex confertifolia Torr. \& Frem.) sites in western Utah. Degraded native communities with even minimal amounts of cheatgrass present are particularly vulnerable to rapid invasion and dominance by cheatgrass following fire (Young et al. 1976). Following fire, there is a potential window of opportunity where drill seeding or other rehabilitation methods may be effectively implemented to slow cheatgrass invasion and reestablish a perennial community that could eventually displace cheatgrass.

Our objectives were to determine the rate of cheatgrass invasion into previously unburned, degraded salt desert shrub communities following fire; to assess the extent to which drill seeding perennial species deterred cheatgrass encroachment; and to determine if native residual species recovery in burned areas could impact cheatgrass. We tested the hypothesis that mechanical disturbance associated with drill seeding would depress cheatgrass production the first year. Subsequent cheatgrass suppression could occur from competition from seeded species that established in the first year.

\section{METHODS}

\section{Study Area}

The study sites were located at US Army Dugway Proving Ground (DPG), Tooele County, Utah. Based on vegetation maps provided by DPG, approximately 33872 ha of training lands are dominated by cheatgrass, of which 11307 ha (33\%) are in the salt desert shrub zone. In addition to cheatgrass displacing native plants and decreasing faunal diversity, it also presents a potentially serious fire hazard. In order to minimize fire hazards and maintain the ecological integrity of training lands, efforts are being made to control cheatgrass at DPG. Large tracts of land dominated by cheatgrass make DPG ideal for cheatgrass research, particularly in relation to developing and testing methods to reclaim cheatgrass-dominated lands and minimize its spread into salt desert shrublands.

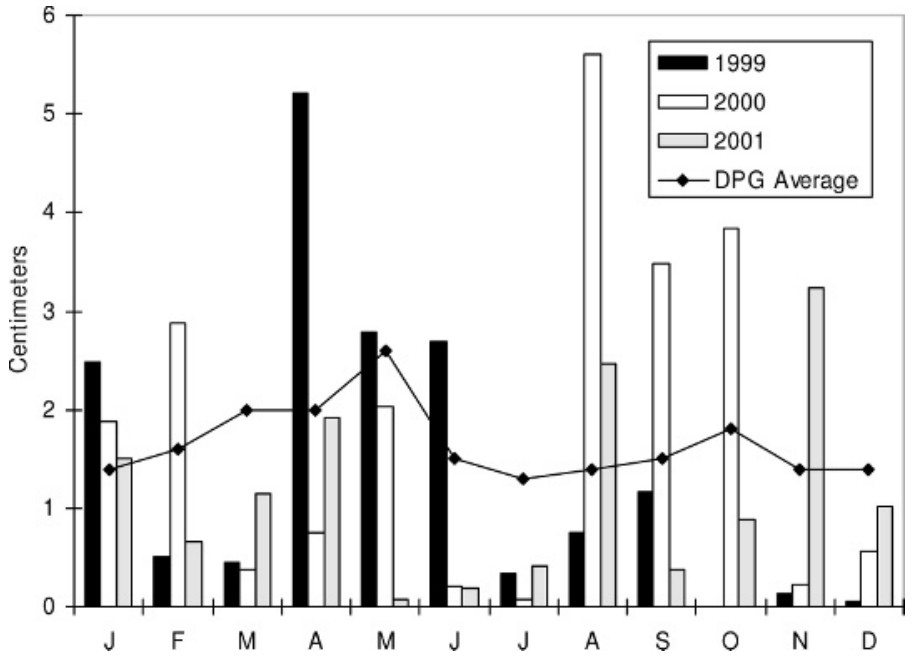

Figure 1. Monthly precipitation for 1999, 2000, and 2001, including the 36-year average for Dugway Proving Ground, Tooele Co, Utah. Total annual precipitation for 1999, 2000, and 2001 were 16.6, 21.9, and $13.9 \mathrm{~cm}$, respectively, with the average total annual precipitation being $19.9 \mathrm{~cm}$ over 36 years.

During the summer of 1998, fires burned more than 11330 ha of rangeland on DPG. Following the fires, 2 burned shrub communities were selected as study sites. One site was dominated by greasewood, the other by black sagebrush and shadscale. Both shrub communities are located on the southwest side of the Cedar Mountains. The greasewood community (UTM coordinates 3-28-133E, 44-60-942N) occurs at $1332-\mathrm{m}$ elevation and receives $150-200 \mathrm{~mm}$ of precipitation annually. Soils are Tooele fine sandy loam saline soils of the Tooele series of coarse-loamy, mixed (calcareous), mesic Typic Torriorthents (NRCS 1999). Currently, this site is occasionally used by mobile artillery units for live-fire training exercises. It has also been used as an impact zone for munitions. Prior to the fires of 1998, we observed that cheatgrass was present but not dominant in this community.

The black sagebrush and shadscale community (UTM coordinates 3-27-805E, 44-66-532N), hereafter referred to as the black sagebrush site, ranges from $1494 \mathrm{~m}$ to $1536 \mathrm{~m}$ in elevation and receives $250-300 \mathrm{~mm}$ of precipitation annually. Soils are Hiko Peak very stony loam soils of the Hiko Peak series of loamy-skeletal, mixed, mesic Xerollic Calciorthids (NRCS 1999). This site has not been actively used for military training exercises. Previous to the 1998 fire, we observed that cheatgrass encroachment was minimal, although high densities of small, single-stem plants were noted growing in patches underneath some shrubs. There is no record that either shrub community burned before the 1998 fires.

Temperatures on DPG range from $-33^{\circ} \mathrm{C}$ to $43^{\circ} \mathrm{C}$ with an annual mean temperature of $11.2^{\circ} \mathrm{C}$ over the last 36 years. Precipitation occurs mainly during the spring months. Pronounced variations in precipitation amounts were observed during the 3 years $(1999,2000,2001)$ of this study (Fig. 1).

\section{Plot Layout and Data Collection}

In each shrub community data were collected in 1-ha 1) burned not-seeded, 2) burned drill seeded, and 3) unburned plots. Each 
Table 1. Seed mix composition and seeded species density for 2000 and 2001 following postfire revegetation at Dugway Proving Ground, Tooele Co, Utah. Seeded species density is shown only for the black sagebrush site since virtually no seeded species survived in the greasewood site. ${ }^{1}$

\begin{tabular}{|c|c|c|c|c|c|c|c|c|}
\hline \multirow[b]{2}{*}{ Origin } & \multicolumn{4}{|c|}{ Drill seed mix } & \multicolumn{2}{|c|}{2000} & \multicolumn{2}{|c|}{2001} \\
\hline & Species & Scientific name & $\%$ of mix & Site & Plants $\cdot \mathrm{m}^{-2}$ & SE & Plants $\cdot \mathrm{m}^{-2}$ & SE \\
\hline I & Crested wheatgrass & Agropyron cristatum & 36.8 & $S / G$ & 22.8 & \pm 2.19 & 15.8 & \pm 1.86 \\
\hline $\mathrm{N}$ & Thickspike wheatgrass & Elymus macrourus & 22.9 & $S / G$ & 0.5 & \pm 0.31 & 0.0 & \pm 0.05 \\
\hline I & Russian wildrye & Psathyrostachys juncea & 11.5 & $S / G$ & 0.6 & \pm 0.07 & 0.3 & \pm 0.07 \\
\hline $\mathrm{N}$ & Great Basin wildrye & Lymus cinereus & 11.5 & $S / G$ & 0.6 & \pm 0.05 & 0.3 & \pm 0.07 \\
\hline $\mathrm{N}$ & Indian ricegrass & Achnatherum hymenoides & 2.9 & $S / G$ & 0.3 & \pm 0.03 & 0.1 & \pm 0.05 \\
\hline $\mathrm{N}$ & Blue flax & Linum lewisii & 2.9 & $S / G$ & 0.2 & \pm 0.07 & 0.3 & \pm 0.12 \\
\hline \multirow[t]{2}{*}{$\mathrm{N}$} & Fourwing saltbush & Atriplex canescens & 11.5 & $S / G$ & 0.0 & \pm 0.03 & 0.1 & \pm 0.03 \\
\hline & \multicolumn{4}{|c|}{ Broadcast seed mix } & \multicolumn{2}{|c|}{2000} & \multicolumn{2}{|c|}{2001} \\
\hline Origin & Species & Scientific name & $\%$ of mix & Site & Plants $\cdot \mathrm{m}^{-2}$ & SE & Plants $\cdot \mathrm{m}^{-2}$ & SE \\
\hline I & Dryland alfalfa & Medicago sativa & 41.6 & $S$ & 0.6 & \pm 0.38 & 0.6 & \pm 0.35 \\
\hline 1 & Yellow sweet clover & Melilotus officinalis & 41.6 & S & 0.6 & \pm 0.31 & 0.0 & \pm 0.25 \\
\hline $\mathrm{N}$ & Wyoming big sagebrush & Artemisia tridentata & 16.8 & S & 0.1 & \pm 0.05 & 0.1 & \pm 0.03 \\
\hline
\end{tabular}

${ }^{1} \mathrm{~N}=$ native; $\mathrm{I}=$ introduced; $\mathrm{S}=$ sagebrush site; $\mathrm{G}=$ greasewood site.

plot type was replicated 3 times per community, giving a total of 9 plots ( 3 plot types $\times 3$ replicates) per site. Drill seeding occurred over the entire burned area with the exception of burned not-seeded plots, which were centered within a burned area. Drill seeded plots were immediately adjacent to notseeded plots. All plots within a community type were within $1 \mathrm{~km}$ of each other. Drill seeded plots were seeded with a rangeland drill at a bulk rate of $15.1 \cdot \mathrm{kg} \cdot \mathrm{ha}^{-1}$ with a perennial grass/forb/shrub seed mix. The seed mix was intended for general fire rehabilitation at DPG and was not specifically designed to be site or community specific. It consisted of both native and introduced species with the majority being crested wheatgrass (Agropyron cristatum L. Gaertner; Table 1; scientific nomenclature follows USDA NRCS [2005] for all species). At DPG, crested wheatgrass has been used extensively for revegetation projects because it establishes quickly, is resistant to spring wildfire, and has been shown to be effective at capturing sites from cheatgrass (D'antonio and Vitousek 1992). Additional species, including Wyoming big sagebrush (Artemisia tridentata var. wyomingensis Beetle \& Young, Welsh), dryland alfalfa (Medicago sativa L.), and yellow sweet clover (Melilotus officinalis L. Pallas.), were broadcast seeded following drilling at the black sagebrush site only. These species were considered inappropriate for the greasewood site because of higher soil salinity. Seeding of the black sagebrush site occurred during the second week of December 1998, while the greasewood site was seeded during the second week of March 1999.

A total of 40 samples were taken along four 100-m permanently fixed transects (10 samples per transect) within each plot. Cheatgrass density was recorded in order to assess the rate of encroachment and evaluate the effectiveness of the drill seeding treatment. We determined cheatgrass density by counting the number of plants $(1$ basal clump $=1$ seedling, regardless of the number of stems) in a $16 \times 25 \mathrm{~cm}$ quadrat. The density of drill seeded species was assessed using a $125 \times$ $25 \mathrm{~cm}$ rectangular frame laid perpendicular to the drill rows so that 4 drill rows were covered with each placement. Each individual seedling counted was lumped into a grass, forb, or shrub category for the first year but afterward were separated by species.

To help clarify plant community response to fire and cheatgrass invasion, we recorded relative frequency (frequency per species/frequency for all species; Smith et al. 1987), canopy cover, and percent basal cover using a $0.25-\mathrm{m}^{2}$ nested frequency quadrat (NFQ) with 8 basal points. Frequency and canopy cover data were used to characterize community composition. For each species occurring in the NFQ, percent canopy cover was estimated ocularly using cover classes $(<1 \%, 1 \%-5 \%, 5 \%-25 \%, 25 \%-50 \%, 50 \%-75 \%, 75 \%-$ $95 \%,>95 \%)$. Percent basal cover was used mainly to assess abiotic factors. Categories included in the basal cover estimate were litter, bare ground, pavement $(2 \mathrm{~mm}$ to $2 \mathrm{~cm})$, rock $(>2 \mathrm{~cm})$, and biological soil crusts.

Density, cover, and frequency values were pooled to get overall averages for plants in each of the experimental plots. To reduce potential edge effects, no sampling occurred within $5 \mathrm{~m}$ of plot borders. Data were gathered after the fire on the following dates: 3-23 June 1999, 5-7 June 2000, and 24-31 May 2001.

Three years after the fire, it was readily apparent that drill seeding had exerted a positive effect on native shrub recovery in the black sagebrush site. Obvious differences in shrub densities were observed between burned drill seeded and burned notseeded plots. To quantify these differences, additional shrub density data were collected during August 2001 (shrub data were not collected in the greasewood site because there were very few shrubs in any treatment). The total number of shrubs were counted using circular transects. At each randomly selected starting point, a stake was pounded into the ground, a measuring tape attached to the stake was stretched to a predetermined length, and the researcher, while holding the tape, walked in a complete circle, counting all shrubs within the circle. Different radii lengths, reflecting various areas of circles, were used to facilitate ease and accuracy in counting shrubs. For example, shadscale in burned not-seeded plots was widely 
dispersed. In order to get sufficient shrub density data on shadscale, it was necessary to use a large circle (17.8-m radius; $1000 \mathrm{~m}^{2}$ ). Because black sagebrush occurred in high densities in unburned plots, a smaller circle $\left(4-\mathrm{m}\right.$ radius; $50 \mathrm{~m}^{2}$ ) was used. Three samples were taken within each replicate of each plot type, giving a total of 9 samples. The mean number of shrubs was computed per treatment and converted to the number of plants $\cdot \mathrm{ha}^{-1}$. Only 4 shrub species were included in the density counts: black sagebrush, shadscale, and the 3 seeded species, four-wing saltbush and big sagebrush.

\section{Statistical Analysis}

Abiotic and temporal factors may influence the success of drill seeding at different sites. Therefore, comparisons of 2 inherently different communities may not be valid. Because of variations in soil types, soil chemistry, elevation, precipitation, and timing of seeding, we analyzed the greasewood and black sagebrush sites separately.

Data were analyzed as a completely randomized design with a 1-way treatment structure with repeated measures (years 1999, 2000, 2001). Repeated-measures analysis of variance (GLM model, SAS Institute 2002) was performed using relative frequency, percent relative cover, and mean densities of cheatgrass to determine significant differences in treatment effects. Factors analyzed in the design were year (1999 vs. 2000 vs. 2001), treatment (burned not-seeded, burned drill seeded, unburned), and year-by-treatment interactions. Where year-bytreatment interactions were significant, we analyzed each year separately using PROC GLM with a Bonferroni multiple comparisons test to determine specific differences in treatment effects. Treatment effects were considered to be significant at $P<0.034$ (alpha $=0.1 / 3$ replicates). We used the ShapiroWilk test for normality and Levene's test for homogeneity of variance. Because of nonnormal distribution, all data were square root transformed (variable +0.50 ; Little and Hills 1978) prior to analysis. $P$ values from both Shapiro-Wilk and Levene's test for homogeneity were not significant $(P>0.05)$, indicating that data were successfully normalized by the square root transformation and means were in fact homogeneous.

\section{RESULTS}

\section{Greasewood Site}

Emergence and Survival of Seeded Species. First-year emergence of seeded species at the greasewood site was very good. In 1999, seeded species emergence in burned drill seeded plots for grasses, forbs, and shrubs were 42.7, 2.4, and 0.24 plants . $\mathrm{m}^{-2}$, respectively. One year later, virtually nothing had survived. No seeded species were noted in the quadrats in either 2000 or 2001. (In both 2000 and 2001, a few individuals of Atriplex canescens [Pursh] Nutt. were observed, however, in some of the drill-rows adjacent to our transects.)

Impact of Drill Seeding on Cheatgrass. There was a significant year-by-treatment interaction $(P<0.05)$ for cheatgrass density. In 1999, approximately 1 year after the fire, cheatgrass densities in burned drill seeded plots were $43 \%$ lower than burned not-seeded plots, 219.1 and 381.9 plants $\cdot \mathrm{m}^{-2}$, respectively, compared to 608.4 plants $\cdot \mathrm{m}^{-2}$ in unburned plots $(P=0.02)$. From 1999 to 2000 , cheatgrass densities in all plots dropped to $<3$ plants $\cdot \mathrm{m}^{-2}$. By the summer of 2001, cheatgrass had rebounded in all treatments. Densities were lowest in the unburned plots $\left(80.1\right.$ plants $\left.\cdot \mathrm{m}^{-2}\right)$ and higher in burned drill seeded (113.9 plants $\left.\cdot \mathrm{m}^{-2}\right)$ and burned not-seeded plots (139.1 plants $\cdot \mathrm{m}^{-2} ; P=0.03$; Fig. 2A). When pairwise Bonferroni comparisons were considered, only differences in cheatgrass densities between unburned and burned seeded plots in 1999 were significant $(P=0.0249)$.

There were no significant differences in cheatgrass frequency between treatments in the greasewood site $(P>0.05$ for all years).

There was a significant year-by-treatment interaction $(P<0.05)$ for cheatgrass cover. In 1999, cheatgrass cover was not different between treatments (Bonferroni comparisons: unburned vs. burned not-seeded, $P=0.068$; unburned vs. burned drill seeded, $P=1.000$; burned not-seeded vs. burned drill seeded, $P=0.1893$; Fig. 2C). The following year, cheatgrass cover was $<1 \%$ in all treatments. By 2001, cheatgrass cover was lowest in the unburned plots $(4.2 \%)$ and highest in burned drill-seeded plots (9.2\%). Pairwise Bonferroni comparisons showed that cheatgrass cover in unburned plots was significantly different than both burned seeded and burned not-seeded plots $(P=0.0028$ and $P=0.0080$ respectively; Fig. 2C), but differences in cheatgrass cover between burned seeded and burned not-seeded plots were not $(P=0.9184)$.

Response of Residual Native and Exotic Species. There was a conspicuous lack of native understory species in the greasewood site prior to burning. Following the fire, the site was quickly dominated by cheatgrass. The only native residual species noted after the fire was greasewood. Burning followed by drill seeding had a greater impact on greasewood cover than burning alone. Greasewood cover in unburned plots was $2.49 \%$ but decreased to $1.48 \%$ and $0.56 \%$ in burned notseeded and burned drill-seeded plots, respectively $(P>0.05)$. Although we noticed that greasewood resprouted more readily in drill seeded plots, there was no apparent impact of its regrowth on cheatgrass.

Percent relative frequency of several exotic annual forbs changed substantially throughout the study. There were significant $(P<0.05)$ year-by-treatment interactions for halogeton (Halogeton glomeratus [Bieb.] C.A. Mey.), bur buttercup (Ranunculus testiculatus [Crantz.] Bess.), Russian thistle (Salsola iberica L.), tumble mustard (Sisymbrium altissimum L.), and clasping pepperweed (Lepidium perfoliatum L.). Halogeton was not present in any treatment in 1999 but was found in all treatments in both 2000 and 2001 (mean frequency for all treatments $=2.3$ and $3.4 \%$, respectively). Bur buttercup, tumble mustard, and pepperweed were present in 1999 and 2001 (mean frequency for all treatments $=13.1 \%$ and $11.4 \%$, respectively) but were virtually eliminated in 2000 $(<1 \%)$. Russian thistle frequency averaged across all treatments increased from 5\% in 1999 to $85 \%$ in 2000 and then declined to $27 \%$ in 2001. Based on Bonferroni comparisons, in 2001, pepperweed, Russian thistle, and tumble mustard showed significant treatment effects $(P=0.0173,0.0038$, 

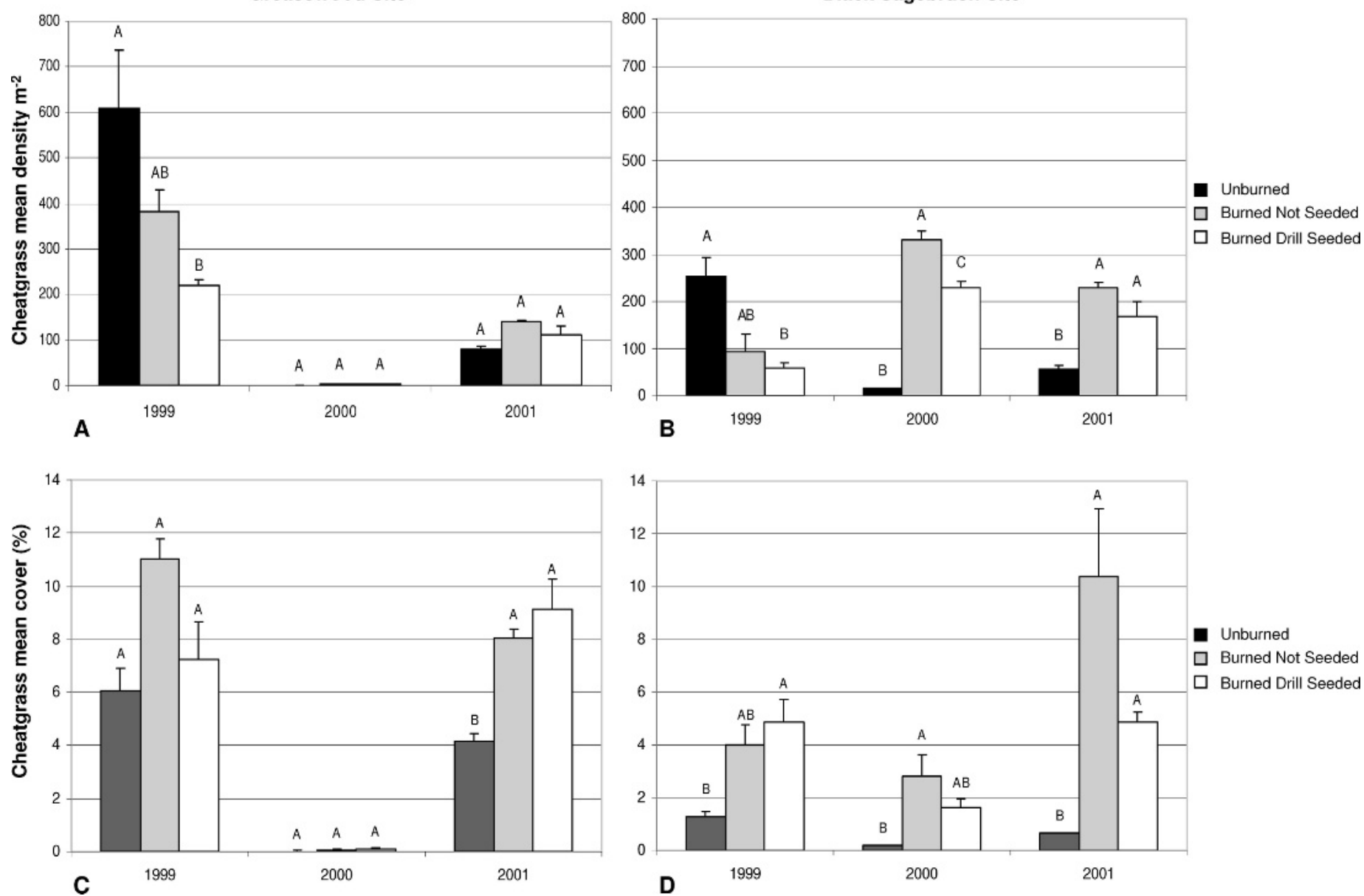

Figure 2. Cheatgrass densities (A, B) and mean relative \% cover (C, D) compared in burned drill seeded, burned not-seeded, and unburned plots over 3 years in greasewood and black sagebrush sites at the Dugway Proving Ground, Tooele Co, Utah. For cheatgrass densities and cover, year $\times$ treatment $=P<0.02$ for both sites; $n=3$.

and 0.0205 , respectively), but halogeton and bur buttercup did not $(P=0.636$ and 0.0561 , respectively). In 2001, cover for all exotic forbs combined was highest in unburned plots $(5.7 \%)$ followed by drill seeded $(3.9 \%)$ and not-seeded $(2.2 \%)$ plots, although these differences were not significant $(P=0.1606)$.

Impact of Fire and Drill Seeding on Abiotic Factors. Fire and drill seeding had a considerable impact on the percent cover of litter, bare ground, and biological soil crusts. In 1999, litter decreased from $54.2 \%$ in unburned plots to $22.8 \%$ in burned not-seeded plots. Litter cover in burned drill seeded plots was $13.8 \%$. This decrease in litter coincides with an increase in bare ground in disturbed sites $(22.7 \%$ in unburned plots, $52.2 \%$ and $75.3 \%$ in burned not-seeded and burned drill seeded plots, respectively). In both 2000 and 2001 there was $<4 \%$ difference between unburned plots and burned not-seeded plots for litter and bare ground cover (litter cover year 2000 and $2001=59.4 \% \pm 2 \%$ and $42.7 \% \pm 2 \%$, respectively; bare ground cover year 2000 and $2001=37.1 \% \pm 2 \%$ and $46.4 \%$ $\pm 2 \%$, respectively). In burned drill seeded plots, litter cover was $32 \%$ lower and bare ground cover $>28 \%$ higher than unburned and not-seeded plots in both 2000 and 2001. Biological soil crust cover decreased from $14.2 \%$ in unburned plots to $11.9 \%$ and $2.4 \%$ in burned not-seeded and burned drill seeded plots, respectively, for 1999. During 2000, biological soil crust cover was $<3 \%$ in any treatment. By 2001, biological soil crust cover was $7.6 \%$ in unburned plots compared to $5.1 \%$ and $1 \%$ in burned not-seeded and burned drill seeded plots, respectively.

\section{Black Sagebrush Site}

Emergence and Survival of Seeded Species. All species included in the seed mix emerged and established in burned drill seeded sites. Densities of seeded grasses, forbs, and shrubs in 1999 were $78.8,15.8$, and 0.35 plants $\cdot \mathrm{m}^{-2}$, respectively. While seeded species densities declined in 2000 by $>85 \%$, cheatgrass densities in burned drill seeded plots increased by $76 \%$ (Fig. 2B). By 2001, densities of seeded grasses, forbs, and shrubs were $16.5,0.9$, and 0.2 plants $\cdot \mathrm{m}^{-2}$, respectively (Table 1).

Following the fire, black sagebrush was completely eliminated from burned sites. However, after 3 years it was obvious that drill seeding successfully promoted the establishment and recovery of other native shrubs. Burned not-seeded plots were almost devoid of shrubs, while the surrounding drill seeded areas showed excellent establishment of four-wing saltbush and an increase in shadscale. Shrub density counts using the circular 
transect method showed densities of 1356 shrubs $\cdot \mathrm{ha}^{-1}$ in burned drill seeded plots compared to 236 shrubs $\cdot$ ha $^{-1}$ in burned not-seeded plots. Unburned plots averaged 11711 shrubs $\cdot \mathrm{ha}^{-1}$. On average, shadscale decreased from 955 plants - $\mathrm{ha}^{-1}$ in unburned plots to 237 plants $\cdot \mathrm{ha}^{-1}$ in burned notseeded plots but increased to 522 plants $\cdot$ ha $^{-1}$ in burned drill seeded sites even though it was not seeded.

Seeded grasses were second only to cheatgrass in mean relative frequency and cover. In burned drill seeded plots, cheatgrass frequency averaged $34.8 \%$ for all years combined, while seeded grasses had a mean frequency of $25.3 \%$. Crested wheatgrass was highest in density, frequency, and cover among all seeded species. Seeded forbs accounted for $8.1 \%$ of all species encountered with alfalfa being most abundant followed by blue flax (Table 1).

Impact of Drill Seeding on Cheatgrass. Drill seeding perennial species in the black sagebrush site impacted cheatgrass density, frequency, and cover. There was a significant $(P<0.05)$ yearby-treatment interaction for both cheatgrass density and cover. When years were analyzed separately, cheatgrass densities were significantly different $(P<0.05)$ between treatments for all 3 years. Densities were consistently lower in burned drill seeded plots than in burned not-seeded plots for all years, but Bonferroni comparisons showed that these differences were significant only for $2000(P=0.0107$; Fig. 2B). In 1999, cheatgrass densities averaged 253 plants $\cdot \mathrm{m}^{-2}$ in unburned plots, 93 plants $\cdot \mathrm{m}^{-2}$ in burned not-seeded plots and 53 plants - $\mathrm{m}^{-2}$ in burned drill seeded plots $(P<0.05$; Bonferroni comparisons: unburned vs. burned not-seeded, $P=0.0527$; unburned vs. burned drill seeded, $P=0.0191$, burned notseeded vs. burned drill seeded, $P=1.000)$. In 2000, cheatgrass densities in unburned plots were only 15 plants $\cdot \mathrm{m}^{-2}$, while burned not-seeded plots and burned drill seeded plots averaged 330 plants $\cdot \mathrm{m}^{-2}$ and 230 plants $\cdot \mathrm{m}^{-2}$, respectively $(P<0.05$; Bonferroni comparisons: unburned vs. burned not-seeded, $P=0.0001$; unburned vs. burned seeded, $P=0.0001)$. In 2001, cheatgrass densities were lowest in unburned plots $(55$ plants $\cdot \mathrm{m}^{-2}$ ) and $27 \%$ lower in burned drill seeded plots (169 plants $\cdot \mathrm{m}^{-2}$ ) than in burned not-seeded plots (230 plants . $\mathrm{m}^{-2} ; P<0.05$; Bonferroni comparisons: unburned vs. burned not-seeded, $P=0.0014$; unburned vs. burned seeded, $P=0.0083$; Fig. 2B).

In 1999 and 2000, cheatgrass cover was $<5 \%$ in any treatment. In 2001, cheatgrass cover increased to $>10 \%$ in burned not-seeded plots compared to $4.9 \%$ and $<1 \%$ in burned drill seeded and unburned plots, respectively $(P<0.05$; Fig. 2D). Bonferroni comparisons showed that cheatgrass cover was significantly lower in unburned plots compared to burned not-seeded plots for $2000(P=0.0082)$ and 2001 $(P=0.0014)$, but differences between burned drill seeded and burned not-seeded plots were never significant.

Differences in relative frequency of cheatgrass between treatments were not significant $(P>0.05)$ for any year; however, the relative frequency of cheatgrass was $37 \%, 25 \%$, and $9 \%$ lower in burned drill seeded plots than burned notseeded plots for 1999, 2000, and 2001, respectively.

Response of Residual Native and Exotic Species. By 2001, percent cover of residual grasses and forbs in burned plots were not significantly different than unburned plots $(P>0.05)$

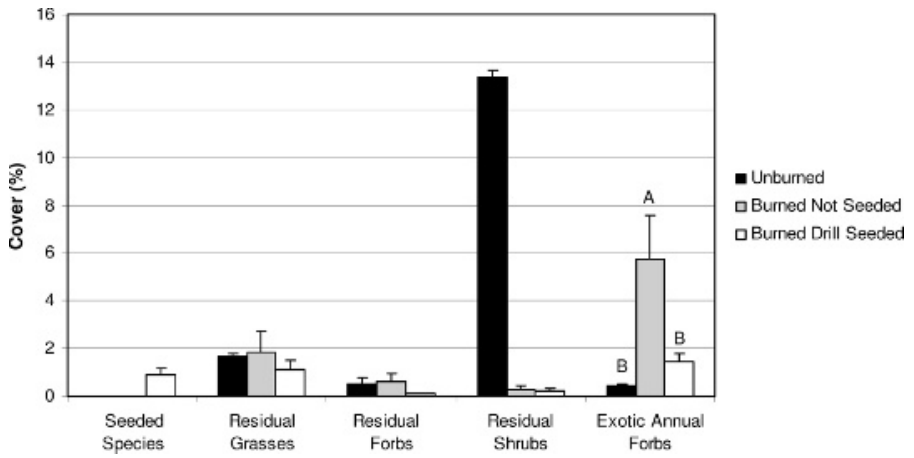

Figure 3. Percent canopy cover of seeded species, residual species, and exotic annual forbs in burned drill seeded, burned not-seeded, and unburned plots in a black sagebrush site 2 years following fire (2001). Residual shrubs $=$ black sagebrush (Artemisia nova A. Nels.), winterfat (Krascheninnikovia lanata [Pursh] A. D. J. Meeuse \& Smit), green rabbitbrush (Chrysothamnus viscidiflorus [Hook.] Nutt.), Ephedra (Ephedra nevadensis S. Wats.), broom snakeweed (Gutierrezia sarothrae [Pursh] Britt. \& Rusby), shadscale (Atriplex confertifolia Torr. \& Frem.), and horsebrush (Tetrademia glabrata Torr. \& Gray). Residual forbs = hoary tansyaster (Machaeranthera canescens [Pursh] Gray), phlox (Phlox hoodii Richards.), and Munro's globemallow (Sphaeralcea munroana [Dougl. ex Lindl.] Spach ex Gray). Residual grasses = bluebunch wheatgrass (Pseudoroegnaria spicata [Pursh] A. Love), galletta (Hilaria jamesii Torr.), Sandberg's bluegrass (Poa secunda J. Presl), and bottle brush squirreltail (Elymus hystrix L.). Exotic forbs $=$ tansymustard (Descurainia sophia L.), redstem storks bill (Erodium cicutarium L.), halogeton (Halogeton glomeratus [Bieb.] C.A. Mey.), bur buttercup (Ranunculus testiculatus [Crantz] Bess.), Russian thistle (Salsola iberica L.), and tumble mustard (Sisymbrium altissimum L.). See Table 1 for seeded species.

indicating natural recovery of many species following the fire (Fig. 3). Shrub cover declined severely in burned plots.

By 2001, based on Bonferroni comparisons, cover of exotic annual forbs was significantly higher $(P=0.0375)$ in burned not-seeded plots $(5.8 \%)$ than either burned drill seeded $(1.5 \%)$ or unburned plots $(<1 \%$; Fig. 3$)$. The pattern was the same for exotic annual forb frequency (burned not-seeded plots $=44.5 \%$; burned drill seeded plots $=22.4 \%$; unburned plots $=13.2 \% ; P=0.0348)$. Halogeton, Russian thistle, and tumble mustard were not present on site in 1999 and 2000 but appeared in all plots in 2001. When lumped and averaged across years, relative frequency of exotic forbs was lowest in unburned plots $(6.4 \%)$ and higher in burned drill seeded $(15.6 \%)$ and burned not-seeded plots $(30.2 \%)$.

Impact of Fire and Drill Seeding on Abiotic Factors. In 1999, cover for litter and bare ground in unburned plots was $21.3 \%$ and $23.1 \%$, respectively. Fire decreased litter to $<7 \%$ and increased bare ground to $>60 \%$ in burned not-seeded and burned drill seeded plots. For 2000 and 2001, litter cover was consistent across all plots (mean $=28.3 \%$; range $=25.8 \%-$ $35.7 \%$ ), while bare ground was $30.1 \%$ in unburned plots and $45.7 \%$ and $52 \%$ in burned not-seeded and burned drill seeded plots, respectively. Biological soil crust cover decreased from $19.9 \%$ in unburned plots to $4.1 \%$ and $2.3 \%$ in burned notseeded and burned drill seeded plots, respectively, for 1999. During 2000 and 2001, biological soil crust cover averaged $13.3 \%$ in unburned plots but $<1.2 \%$ in the other treatments. 


\section{DISCUSSION}

We observed general trends in both the greasewood and black sagebrush sites. In 1999, unburned plots in both sites had a higher density of cheatgrass compared to burned plots (Figs. 2A and 2B). This may give the impression that the unburned plots were dominated by cheatgrass. In reality, most of the cheatgrass in these areas were small, single-stemmed plants with few caryopses that were confined to dense patches under shrubs and dried Russian thistles. This is not uncommon because shrubs act as nurse plants ameliorating harsh environmental conditions and are often the foci of invasion for cheatgrass (Meyer et al. 2001). Few plants were noted in the shrub interspaces. In contrast, cheatgrass in burned areas was much more robust with multiple stems per plant, had many caryopses, and was distributed more evenly. In spite of the high density of cheatgrass in unburned plots, cover class estimates showed that cheatgrass cover was lowest in unburned plots in all 3 years in both shrub communities, suggesting that density does not always equate with dominance (Figs. 2C and 2D). Even though cheatgrass was a relatively minor component of both native shrub communities prior to burning, it quickly became dominant following the fire.

Following fire, there is a decrease in resource competition and an opening of available niches (Blank et al. 1994). The rapid germination and growth of cheatgrass enables it to fill these niches and persist (Melgoza et al. 1990). We predicted that occupation of available niches by seeded species and the resulting competition for moisture and nutrients would minimize cheatgrass encroachment and cause cheatgrass densities to decrease over time. Because almost no seeded species survived to compete with cheatgrass in the greasewood site and because cheatgrass densities were consistently lower in drill seeded versus not-seeded plots, we initially postulated that soil disturbance buried cheatgrass too deep to germinate. Soils in the greasewood site are soft and easily turned. However, within the same time period that our study was conducted, another study by Meyer et al. (2001) on DPG showed that during favorable moisture patterns, moderate soil disturbance significantly increased cheatgrass recruitment and seed production. Conversely, severe soil disturbance during dry periods either had no effect or significantly decreased cheatgrass recruitment. Results from Meyer et al. (2001) lead us to believe that the decrease of cheatgrass in drill seeded plots at the greasewood site was a combination of severe soil disturbance and extremely dry conditions. Meyer et al. (2001) concluded that cheatgrass invasion in salt desert shrublands may be more dependent on moisture than on disturbance. Evans et al. (1970), Davis et al. (2000), and Bates et al. (2005) observed pronounced variation in the growth and phenology of cheatgrass because of fluctuations in precipitation; our observations were similar. From 1999 to 2000, cheatgrass densities in unburned plots dropped from 608.4 to 0.64 plants $\cdot \mathrm{m}^{-2}$ and across all plots frequency declined from $42 \%$ to $8 \%$. This decrease in cheatgrass coincides with much lower precipitation during critical growth periods (Fig. 1).

Fire and drill seeding had a considerable impact on the percent cover of litter and bare ground. Bates et al. (2004) observed increased cheatgrass in areas with high litter. Evans and Young $(1970,1972)$ emphasized the importance of litter reduction as a means of minimizing the number safe sites for cheatgrass seed germination. Results of our study suggest that litter removal as a means of reducing safe sites is most effective when done with little or no soil disturbance. Even though litter was greatly reduced and cheatgrass densities were consistently lower in drill seeded plots (although not always statistically different based on Bonferroni comparisons), the creation of water catchments in the drill furrows and the increase in bare ground appeared to promote the growth of exotic annual forbs. Exotic annual forbs are common invaders in salt desert shrublands following disturbance. Bare ground cover increased substantially in both sites following disturbance by fire and drill seeding. This may have opened invasion niches for exotic forbs to fill. As with cheatgrass, some exotic forbs may be more dependent on moisture than disturbance during periods of drought. However, the same does not appear to be true for Russian thistle. In the greasewood site, bur buttercup, tumble mustard, and pepperweed were present in 1999 and 2001 (mean frequency for all treatments $=13.1 \%$ and $11.4 \%$, respectively) but were virtually eliminated in $2000(<1 \%$ frequency) when spring and summer precipitation were well below average (Fig. 1). In contrast, across all plots Russian thistle frequency increased from $5 \%$ in 1999 to $85 \%$ in 2000 . Although exotic forbs increased following disturbance in both sites, cheatgrass can outcompete many exotic forb species, including halogeton, tumble mustard, and Russian thistle, and will likely remain a dominant weedy species over time.

In both sites, fire and soil disturbance decreased cover of biological soil crusts. Biological soil crusts are important for maintaining soil stability and retaining soil moisture and nutrients and may influence the germination and establishment of vascular plants (Belnap 1994). Compared to unburned plots in our study, the combined impact of fire and drill seeding decreased biological soil crust cover by $86 \%$ in the greasewood site and by $93 \%$ in the black sagebrush site. On DPG, Burnham (2001) observed lesser amounts of cheatgrass where biological soil crusts were undisturbed. Similar observations were made in southern Utah by Evangelista et al. (2004). In these areas, crust disturbance was associated with higher amounts of cheatgrass, implying a resistance to invasion by cheatgrass. Crusts are slow to recover from severe disturbance, sometimes requiring 40 years or more to recolonize even small areas (Belnap 1994). Considering their ecological importance in semiarid ecosystems and their potential to resist cheatgrass invasion, the impact of soil-disruptive rehabilitation methods on biological soil crusts should be considered prior to implementation.

Seeded species in the greasewood site germinated but did not establish. This was likely due to low precipitation during critical growth periods (Fig. 1), drought conditions that persisted through summer months, and the saline soils characteristic of greasewood communities. Had there been more normal precipitation during the second year, we may have had increased seedling survival. Other seeding trials in similar greasewood sites in northern Utah have demonstrated that it is possible for seeded species to establish and persist (Britton et al. 1999).

In the black sagebrush site, seeded species densities decreased during the second year of the study while at the same time cheatgrass densities increased (Fig. 2B). This may have resulted partially from grazing pressure from feral horses. Feral horses 
roam freely on DPG, and a band of horses occupies the study region year-round. Following drill seeding, the new growth of palatable plants attracted horses to the sites, and many of the seeded species were cropped nearly to the ground. Grazing combined with drought conditions may have reduced seeded species. We also observed that hoof prints from the horses acted as catchments for both cheatgrass seed and water, promoting higher cheatgrass densities. There was no indication that horses utilized the greasewood site.

By 2001, seeded species densities in the black sagebrush site increased substantially. Because data were collected from the same points in consecutive years, it may seem unusual that perennial plant densities would show a sharp decline in 2000 but then rebound in 2001. It is possible that there was less grazing pressure by the horses in 2001, that seedlings may have appeared to be dead in 2000 because of the dry conditions and were not counted even though they were still alive, or that densities of drill seeded species may have increased in 2001 because dormant seeds germinated.

We thought it unusual that shadscale densities increased in the black sagebrush site in burned drill seeded plots relative to burned not-seeded plots. Shadscale is not known to resprout after fire (West 1994) and was not included in our seed mix. However, the drill seeding process appeared to stimulate its recovery. This may have resulted from increased moisture in the drill rows or from soil churning that brought dormant seeds closer to the surface where more favorable environmental conditions promoted germination.

In a landscape scale fire rehabilitation study, Thompson et al. (2006) showed that even minimal establishment from seeded species following fire is enough to suppress annual weeds. In the black sagebrush site, drill seeded grasses averaged 16.5 plants $\cdot \mathrm{m}^{-2}$, while four-wing saltbush and shadscale combined averaged 1356 plants $\cdot \mathrm{ha}^{-1}$. Drill seeded species cover was minimal because most plants were not mature (Fig. 3). Nevertheless, as drill seeded species mature and expand their root systems and become more competitive, we predict that cheatgrass and other annual weeds will continue to decline. Burned areas that were not drill seeded, however, will likely remain in a degraded state dominated by exotic annual weeds (Thompson et al. 2006). Residual species in burned areas that were not seeded may increase in abundance over time, but it is unlikely that they will recolonize to the point of dominance.

\section{MANAGEMENT IMPLICATIONS}

Our study showed that cheatgrass and other exotic annual weeds can quickly invade burned sites in salt desert shrublands. By the end of the study, cheatgrass density and cover were higher on burned plots, whether seeded or not. The emergence and survival of seeded species in the 2 sites was highly variable, yet there was still a trend of lower densities of cheatgrass in burned drill seeded plots versus burned not-seeded plots in both shrub communities, although these differences were not always statistically different based on Bonferroni comparisons. Additionally, cover of exotic annual forbs was lower on seeded plots than on unseeded plots and did not differ in cover from unburned plots. This emphasizes the importance of postfire intervention to reduce annual weed invasion.
Cheatgrass is still a relatively minor component of many salt desert shrublands in the Great Basin of North America, but its range continues to expand. As fires become more common in salt desert shrublands, attempts to restore sites before invasive species like cheatgrass become fully established may help curb the magnitude of invasion (Bakker and Wilson 2004) and increase the likelihood of maintaining a functional ecosystem. Thus, there is a need to identify reclamation techniques appropriate to these areas. Although germination and survival of drill seeded species varied between sites in this study, drill seeding following fire did suppress cheatgrass and help in reestablishing a perennial community in the black sagebrush site. Had there been more moisture during the second growing season, drill seeded species may have fared better all around but especially in the greasewood site. Even moderate success from drill seeding could suppress cheatgrass and other annual weeds in the long run.

\section{ACKNOWLEDGMENTS}

The authors would like to thank Duane Smith for operating the rangeland drill and the Dugway field crew for assisting in data collection. We thank Mark Evans, professor of statistics, Washington State University, and Bruce Roundy, professor of rangeland science, Brigham Young University, for statistical guidance. We appreciate the comments of multiple reviewers which greatly improved the manuscript.

\section{LITERATURE CITED}

BAKKeR, J. D., AND S. D. WiLson. 2004. Using ecological restoration to constrain biological invasion. Journal of Applied Ecology 41:1058-1064.

Bates, J. D., R. F. Miller, and T. Svejcar. 2005. Long-term successional trends following Western Juniper cutting. Rangeland Ecology \& Management 58:533-541.

Bates, J., T. Svejcar, and R. Miller. 2004. Forage production in a cut juniper woodland. In: T. Svejcar and J. Bates [EDs.]. Current forage and livestock production research, Special Report, June 2004. Agricultural Experiment Station, Oregon State University and USDA-Agricultural Research Service. $p$ 24-31.

Belnap, J. 1994. Potential role of cryptobiotic soil crusts in semiarid rangelands. In: S. B. Monson and S. G. Kitchen [EDs.]. Proceedings—Symposium on ecology, management, of annual rangelands, Boise, ID. General Technical Report INTGTR-313. USDA Forest Service Intermountain Research Station, Ogden, UT. p 179-185.

Blank, R. R., F. Allen, and J. A. Young. 1994. Growth and elemental content of several sagebrush-steppe species in unburned and post-wildfire soil and plant effects on soil attributes. Plant and Soil 164:35-41.

Britton, M. V., V. J. Anderson, R. D. Horrocks, and H. Horton. 1999. Evaluation of plant materials for use in reclamation of disturbed rangelands in semiarid areas of northern Utah. In: S. B. Monsen, R. Stevens, R. I. Tausch, R. Miller, and S. Goodrich [EDS.]. Proceedings: Ecology and management of pinyon-juniper communities within the interior west. RMRS-P9. Ogden, UT: USDA Forest Service, Rocky Mountain Research Station. p 339-345.

Burnham, J. 2001. Biological soil crusts resist cheatgrass invasion in different vascular plant communities in Utah's west desert [honors thesis]. Provo, UT: Brigham Young University. 22 p. Available from Brigham Young University, Provo, UT.

D'antonio, C. M., And P. M. Vitousek. 1992. Biological invasion by exotic grasses, the grass/fire cycle, and global change. Annual Review of Ecology and Systematics 23:63-87.

Davis, M. A., J. P. Grime, and K. Thompson. 2000. Fluctuating resources in plant communities: a general theory of invasibility. Journal of Ecology 88:528-534. 
Dobrowolski, J. P., AND K. EwIng. 1990. Vegetation dynamics and environmental attributes of a Great Basin valley exhibiting widespread shrub dieback. In: E. D. McArthur, E. M. Romney, S. D. Smith, and P. T. Tueller [comps.]. Proceedings-Symposium on cheatgrass invasion, shrub die-off, and other aspects of shrub biology and management, Las Vegas, NV. General Technical Report INT-276. USDA Forest Service Intermountain Research Station, Ogden, UT. p 103-114.

Evangelista, P., T. J. Stohlgren, D. Guenther, and S. Stewart. 2004. Vegetation response to fire and postburn seeding treatments in juniper woodlands of the Grand Staircase-Escalante National Monument, Utah. Western North American Naturalist 64:293-305.

Evans, R. A., H. R. Holbo, R. E. Eckert, and J. A. Young. 1970. Functional environment of downy brome communities in relation to weed control and revegetation. Weed Science 18:154-162.

Evans, R. A., And J. A. Young. 1970. Plant litter and establishment of alien annual weed species in rangeland communities. Weed Science 18:697-703.

Evans, R. A., And J. A. Young. 1972. Microsite requirements for establishment of annual rangeland weeds. Weed Science 20:350-356.

Harper, K. T., R. Van Buren, and S. G. Kitchen. 1996. Invasion of alien annuals and ecological consequences in salt desert shrublands of western Utah. In: J. R. Barrow, E. D. McArthur, R. E. Sosebee, and R. J. Tausch [comps.]. Proceedings-Symposium on shrubland ecosystem dynamics in a changing environment, Las Cruces, NM. General Technical Report INT-GTR-338. USDA Forest Service Intermountain Research Station, Ogden, UT. p 58-65.

KnapP, P. A. 1996. Cheatgrass dominance (Bromus tectorum L.) in the Great Basin Desert: history, persistence and influence to human activities. Global Environmental Change 6:37-52.

LitTle, T. M., AND F. J. Hills. 1978. Agricultural experimentation: Design and analysis. New York, NY: John Wiley and Sons. 350 p.

Melgoza, G., R. S. Nowak, and R. J. Tausch. 1990. Soil water exploitation after fire: competition between Bromus tectorum (cheatgrass) and two native species. Oecologia 83:7-13.

Meyer, S. E., S. C. Garvin, and J. Beckstead. 2001. Factors mediating cheatgrass invasion of intact salt desert shrubland. In: D. E. McArthur and D. J. Fairbanks [comps]. Shrubland ecosystem genetics and biodiversity: Proceedings. RMRSP-21. Provo, UT: USDA Forest Service, Rocky Mountain Research Station. p 224-232.
[NRCS] Natural Resources Conservation Service. 1999. Soil survey of Tooele Co. Utah. USDA Soil Conservation Service, Salt Lake City, UT.

SAS InSTITUTE. 2002. User's guide. Release 8.03. Cary, NC: SAS Institute, Inc. 1032 p.

Smith, S. D., S. C. Bunting, And M. Hironaka. 1987. Evaluation of the improvement in sensitivity of nested frequency plots to vegetational change by summation. Great Basin Naturalist 47:299-307.

Smith, S. D., and R. S. Nowak. 1990. Physiological ecology of plants in the intermountain lowlands. In: C. B. Osmond, L. F. Pitelka, and G. Hidy [EDs.]. Ecological studies. Volume 79. Plant biology of the basin and range. New York, NY: Springer-Verlag. $375 \mathrm{p}$.

Thompson, T. W., B. A. Roundy, E. D. McArthur, B. D. Jessop, B. Waldron, and J. N. Davis. 2006. Fire rehabilitation using native and introduced species: a landscape trial. Range Ecology \& Management 59:237-248.

[USDA, nRCS] US Department of Agriculture, Natural Resources Conservation Service. 2005. The PLANTS database. Version 3.5. Available at: http:// plants.usda.gov. Accessed 7 November 2005.

WEST, N. E. 1994. Effects of fire on salt-desert shrub rangelands. In: S. B. Monson and S. G. Kitchen [EDS.]. Proceedings-Symposium on ecology, management, of annual rangelands, Boise, ID. General Technical Report INT-GTR-313. USDA Forest Service Intermountain Research Station, Ogden, UT. p 71-74.

Whisenant, S. G. 1990. Changing fire frequencies on Idaho's Snake River Plains: ecological and management implications. In: E. D. McArthur, E. M. Romney, S. D. Smith, and P. T. Tueller [CoMPS.]. Proceedings-Symposium on cheatgrass invasion, shrub die-off, and other aspects of shrub biology and management, Las Vegas, NV. General Technical Report INT-276. USDA Forest Service Intermountain Research Station, Ogden, UT. p 4-10.

Young, J. A., And R. A. Evans. 1973. Downy brome-intruder in the plant succession of big sagebrush communities in the Great Basin. Journal of Range Management 26:410-415.

Young, J. A., And R. A. Evans. 1978. Population dynamics after wildfires in sagebrush grasslands. Journal of Range Management 31:283-289.

Young, J. A., R. A. Evans, and R. E. Eckert. 1969. Population dynamics of downy brome. Weed Science 17:20-26.

Young, J. A., R. A. Evans, and R. A. Weaver. 1976. Estimating potential downy brome competition after wildfires. Journal of Range Management 29:322-325. 